\title{
Investigating Contributions of Total Column Ozone Variation on Some Meteorological Parameters in Nigeria
}

\author{
Eucharia Chidinma Okoro*, Francisca Nneka Okeke, Lilian Chinenyenwa Omeje \\ Department of Physics and Astronomy, Faculty of Physical Sciences, University of Nigeria, Nsukka, Nigeria \\ Email: *eucharia.okoro@unn.edu.ng
}

How to cite this paper: Okoro, E.C., Okeke, F.N. and Omeje, L.C. (2022) Investigating Contributions of Total Column Ozone Variation on Some Meteorological Parameters in Nigeria. Atmospheric and Climate Sciences, 12, 132-149.

https://doi.org/10.4236/acs.2022.121010

Received: December 5, 2021

Accepted: January 17, 2022

Published: January 20, 2022

Copyright (c) 2022 by author(s) and Scientific Research Publishing Inc. This work is licensed under the Creative Commons Attribution International License (CC BY 4.0).

http://creativecommons.org/licenses/by/4.0/

\begin{abstract}
The relationship between some meteorological parameters and variation of total column ozone (TCO) concentration in Nigeria is studied from 1998-2012. The results using a descriptive analysis revealed a seasonal ozone variation having the same trend in all the stations during the period of study. High variability of TCO occurred between December and March coinciding with the period of dry season and low variability of TCO was observed in August coinciding with the period of rainy season. The observed trends in all the stations show that the TCO variation in Nigeria is mostly caused by natural occurrences. Calabar and Port Harcourt stations showed a high percent of TCO variability, while Kano and Maiduguri indicated a low percentage of TCO variability. Using Spearman correlation analysis, TCO concentration has a strong negative correlation with temperature in some stations with correlation coefficient (r) $(-0.8392,-0.8531,-0.7832,-0.8881$ and -0.7902$)$ for Calabar, Port Harcourt, Makurdi, Lagos and Ilorin respectively. Kano and Maiduguri showed a weak positive correlation coefficient (r) 0.4965 and 0.3776 respectively. Positive correlation observed in Kano and Maiduguri could be as a result of high dehydration of water vapour in these stations due to seasonal harmattan and latitudinal effects. Probably, some of the substances that could deplete ozone such as $\mathrm{HCl}$, aerosol are soluble in water thereby being washed off by rain during wet season leading to maximum TCO concentration during rainy season. Consequently, the observed phenomenon is through transportation of ozone content through the influence of Brewer-Dobson circulation. Again, during wet season, there is the mechanism of low pressure and lower tropopause height phenomenon, therefore, total ozone enhancement. Interestingly, variation in TCO is part of symbolic tools for tropospheric meteorology alteration and this invariably leads to climate change.
\end{abstract}




\section{Keywords}

Total Column Ozone, Temperature, Rainfall, Seasonal, Correlation

\section{Introduction}

Atmospheric ozone $\left(\mathrm{O}_{3}\right)$ is the key trace constituent that participates in the chemistry and radiation of the earth's middle atmosphere. Ozone is classified into two based on altitude as tropospheric ozone, which extends to about $20 \mathrm{~km}$ above the surface and stratospheric ozone, which starts from tropopause just at approximate height of $20 \mathrm{~km}$ and extends to a height of $52 \mathrm{~km}$. Stratospheric ozone is one of the most important constituents in the middle atmosphere, because it is the only atmospheric species that effectively absorbs ultraviolet (UV) solar radiation from 2000 to $3000 \AA$, thereby protecting plant and animal lives from exposure to harmful radiation. Negative variation of this layer could lead to excessive absorption of ultraviolet (UV) radiations that could destroy human beings and ecosystem [1] [2] [3] [4] [5]. The production of ozone in the troposphere occurs through tropospheric-stratospheric exchange that causes the transport of stratospheric air, rich in ozone, into the troposphere and production of ozone through a reaction between sunlight and volatile organic compounds (VOC) and nitrogen oxides, some of which are produced by human activities.

The amount of ozone in troposphere and lower stratosphere, in general, depends on both dynamics and chemistry of the atmosphere. The dynamics influences include wave driving the stratospheric circulation. In stratosphere, transport and wind motion are interconnected to the troposphere. Transport process only redistributes ozone from one place to another [6] [7] [8]. Ozone can also be produced and destroyed through photochemical process [2].

[9] studied the global variations of daily total column ozone using datasets complied from Total Ozone Mapping Spectrometer (TOMS) and Ozone Monitoring Instruments (OMI). They concluded that the decreases in ozone trends in the southern hemisphere are greater than the reduction noted in the northern hemisphere and at a greater rate than reported in the literature. They attributed this result to the effect of the ozone hole developed at the South Pole.

Furthermore, few studies have been carried out on the relationship between some meteorological parameters and ozone variation in Lagos e.g. [7] [10] [11] [12]. These studies were limited to one climatic zone due to lack of availability of data and the data used was stratospheric ozone. However, [13] covered many climatic zones in Nigeria using elevated humidity together with temperature and stratospheric ozone whereas, our study is focused on total ozone content and as well considered other meteorological elements such as rainfall and temperature. Also, [10] considered total ozone content and different atmospheric circulations such as ENSO, QBO. Our study is based on the effects of total ozone content variation on meteorological parameters or elements and not the reverse as hav- 
ing been previously studied. Hence, it is pertinent to carry out a study on the effects of total ozone content variation on meteorological parameters encompassing all the climatic zones in Nigeria. Due to the severity of ozone depletion on health and ecosystem in general; the study of ozone variation on meteorological climate that leads to climate change can never be over-emphasized.

\section{Sources of Data}

The daily means of total ozone data were obtained from Earth Probe Total Ozone Mass Spectroscopy (EPTOMS); this was obtained from a NASA public data website. Similarly, temperature and rainfall data were obtained from Nigerian Meteorological Agency (NIMET) Lagos and both datasets spanned from 1998 to 2012 (a total period of 15 years).

\section{Materials and Methods}

Nigeria lies between latitudes $4^{\circ} \mathrm{N}$ and $14^{\circ} \mathrm{N}$ and longitudes $2^{\circ} \mathrm{E}$ and $15^{\circ} \mathrm{E}$. The climate of this region is divided into dry and rainy seasons occurring in the months of October to March and April to September annually, respectively. Due to location of a station, some cities experience longer wetness or dryness as the case may be. The specific areas in Nigeria studied are Kano $\left(12^{\circ} \mathrm{N}, 8^{\circ} \mathrm{E}\right)$, Ilorin $\left(8^{\circ} \mathrm{N}, 2^{\circ} \mathrm{E}\right)$, Maiduguri $\left(12^{\circ} \mathrm{N}, 13^{\circ} \mathrm{E}\right)$, Makurdi $\left(7^{\circ} \mathrm{N}, 8^{\circ} \mathrm{E}\right)$, Port Harcourt $\left(4^{\circ} \mathrm{N}\right.$, $\left.7^{\circ} \mathrm{E}\right)$, Calabar $\left(4^{\circ} \mathrm{N}, 8^{\circ} \mathrm{E}\right)$ and Lagos $\left(6^{\circ} \mathrm{N}, 3^{\circ} \mathrm{E}\right)$. The choice of selection of these stations was based on four types of climatic zones in Nigeria: Guinea Savanna (Ilorin and Makurdi), Sudan Savanna (Kano and Maiduguri), Rainforest (Port Harcourt) and Mangrove (Calabar and Lagos).

The average of the monthly mean ozone and the yearly values of ozone for each station were computed from the daily values using Equation (1) and (2) respectively.

$$
\bar{M}_{\mathrm{O}_{3}}=\frac{1}{n} \sum_{i=1}^{n} \bar{D}_{\mathrm{O}_{3} i}
$$

where $n$ is the number of days in a month (i.e., 28, 29, 30, or 31), $\bar{M}_{\mathrm{O}_{3}}$ is the monthly mean ozone values and $\bar{D}_{\mathrm{O}_{3}}$ is the daily ozone values.

$$
Y_{\mathrm{O}_{3}}=\frac{1}{n} \sum_{i=1}^{n} M_{\mathrm{O}_{3} i}
$$

where $n$ is the number of months in a year, $Y_{\mathrm{O}_{3}}$ is the yearly ozone values and $M_{\mathrm{O}_{3} i}$ is monthly ozone value.

The average of the monthly mean temperature and rainfall for the period of 15 years for each station were computed from monthly values using Equations (3a) and (3b) respectively

$$
\bar{M}_{T}=\frac{1}{n} \sum_{i=1}^{n} M_{T_{i}}
$$

and 


$$
\bar{M}_{R}=\frac{1}{n} \sum_{i=1}^{n} M_{R_{i}}
$$

where $n$ is the number of days in a month, $\bar{M}_{T}$ and $\bar{M}_{R}$ are the average monthly values for temperature and rainfall, respectively. $M_{T_{i}}$ and $M_{R_{i}}$ are the monthly values for temperature and rainfall.

In order to determine the relationship between ozone concentration and meteorological parameters, Spearman's rank correlation coefficient was used. The Spearman's rank correlation coefficient denoted by $r$, of two variables $x$ and $y$ is given by the expression (3c):

$$
r_{x y}=1-\frac{6 \sum_{i=1}^{n} d_{i}^{2}}{n\left(n^{2}-1\right)}
$$

where $d_{i}$ is the difference between the ranks of the corresponding values of $x$ and $y$, and $\mathrm{n}$ is the number of the pairs of values.

\section{Results and Discussions}

The monthly variability of total ozone content in the climatic zones of Nigeria was displayed in Figures 1-7. The Figures indicate the degree of variance in the monthly concentration of ozone with maximum variability occurring in the months of November, December, January and February and low variability ozone occurring in July and August. It was equally observed that variation of ozone concentration has similar trend in all the stations.

Months of high variability of ozone concentration in all the stations coincided with the period of dry season and low variability of ozone concentration coincided with the period of rainy season. This ozone variation observed could possibly be attributed to atmospheric eddy effects. The eddy effects have strong tendency to give a persistently one-way pump action whose strength varies seasonally and in which air is gradually withdrawn from the tropical stratosphere

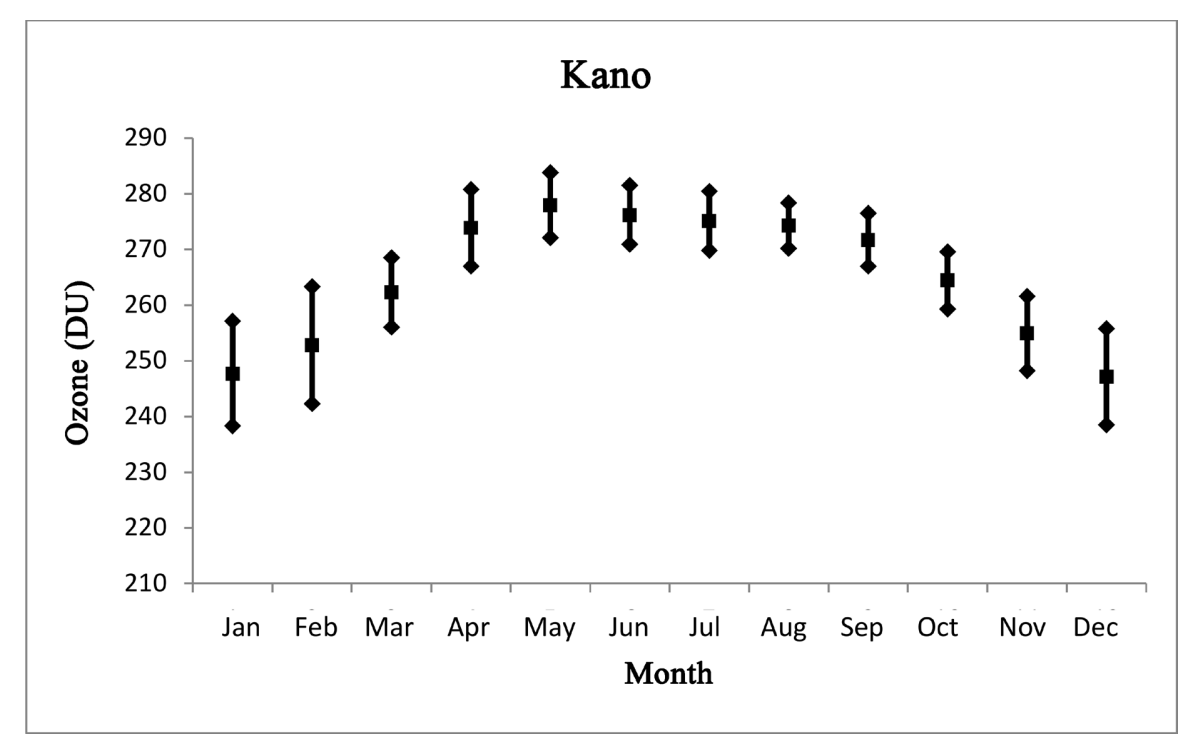

Figure 1. Monthly variation of ozone concentrations in Kano (1998-2012). 


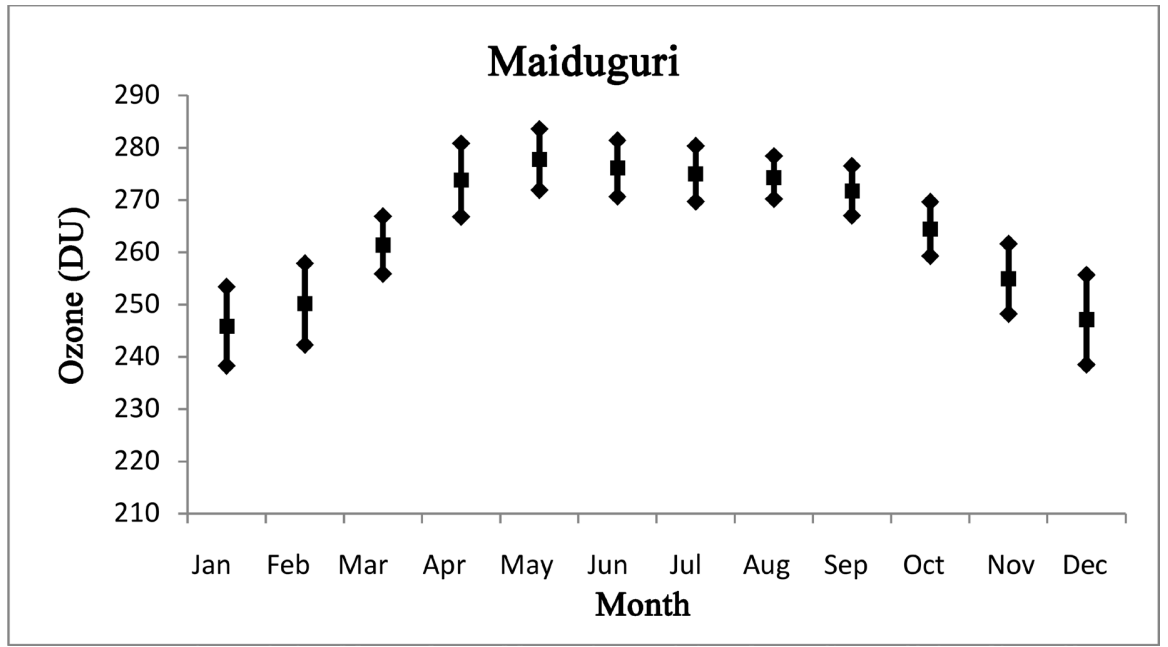

Figure 2. Monthly variation of ozone concentrations in Maiduguri (1998-2012).

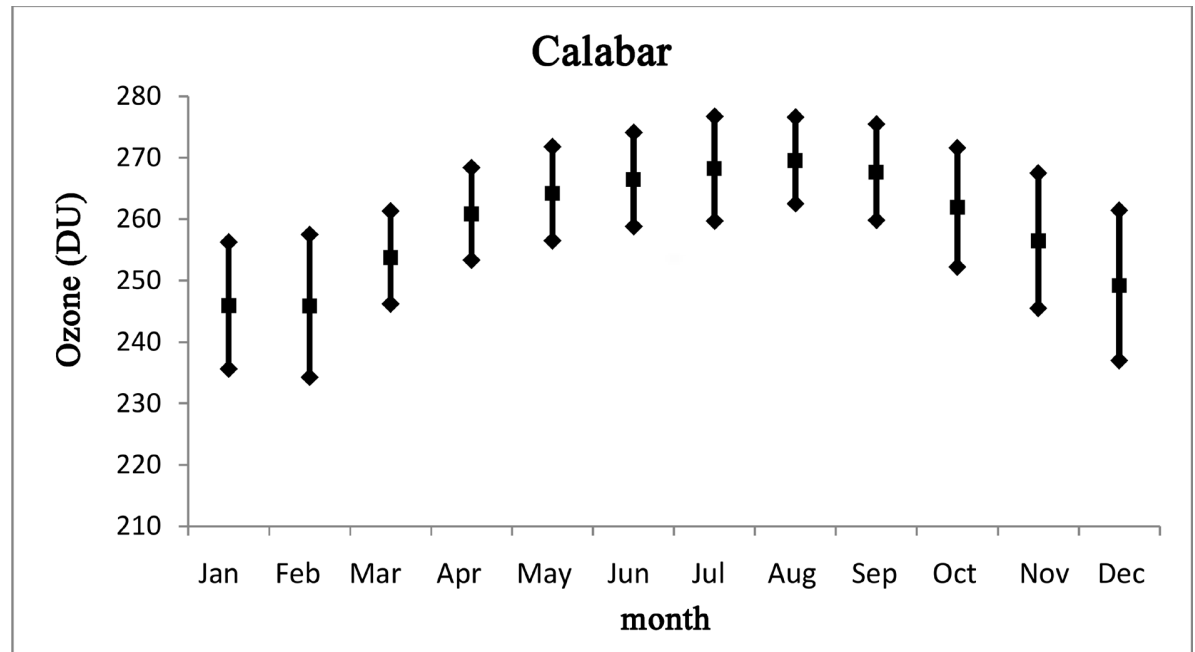

Figure 3. Monthly variation of ozone concentrations in Calabar (1998-2012).

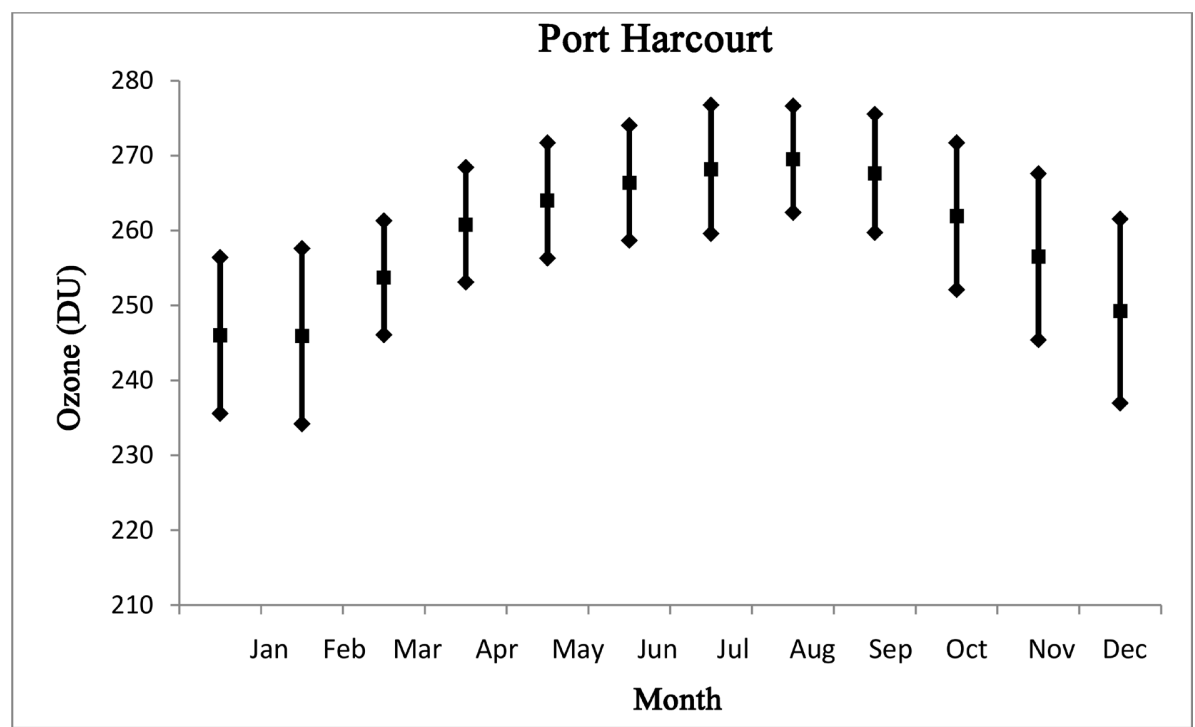

Figure 4. Monthly variation of ozone concentrations in Port Harcourt (1998-2012). 


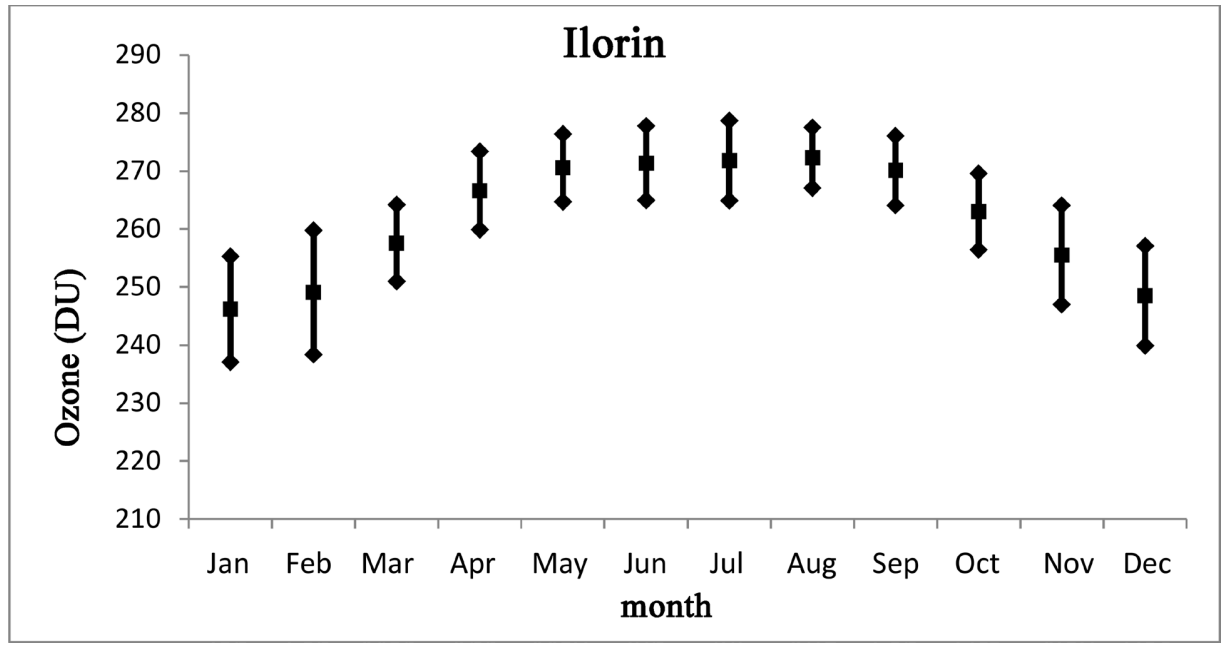

Figure 5. Monthly variation of ozone concentrations in Ilorin (1998-2012).

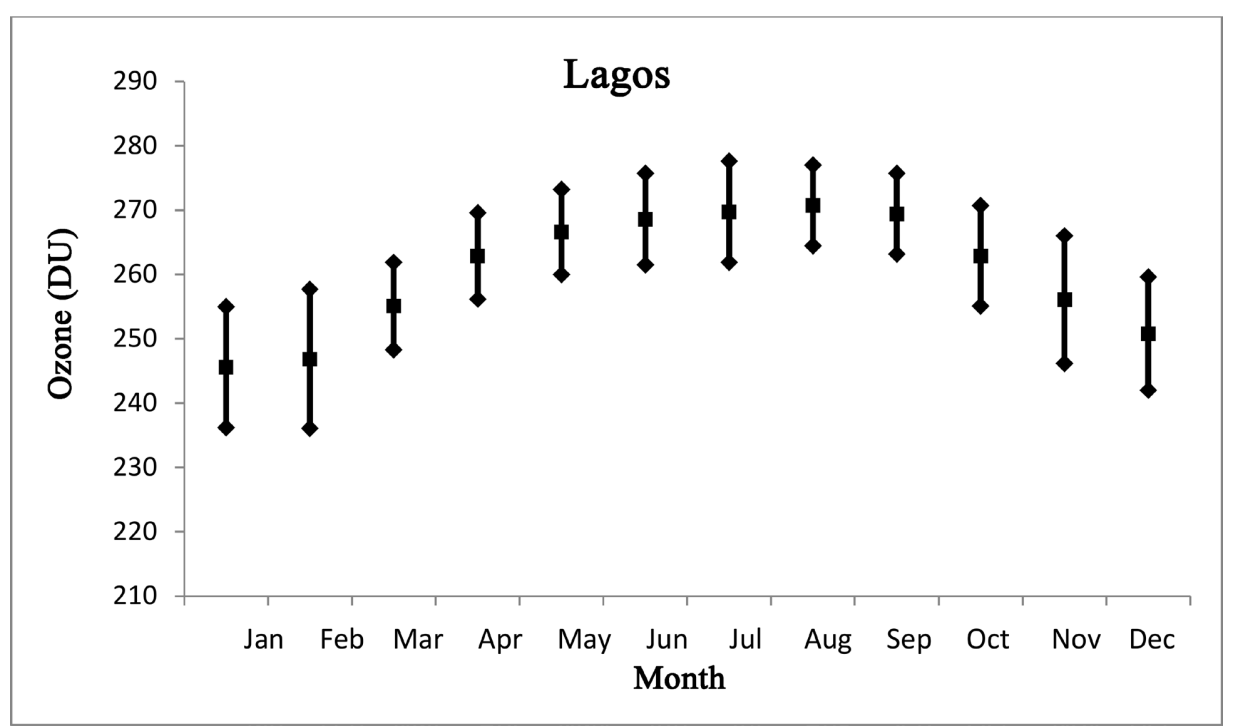

Figure 6. Monthly variation of ozone concentrations in Lagos (1998-2012).

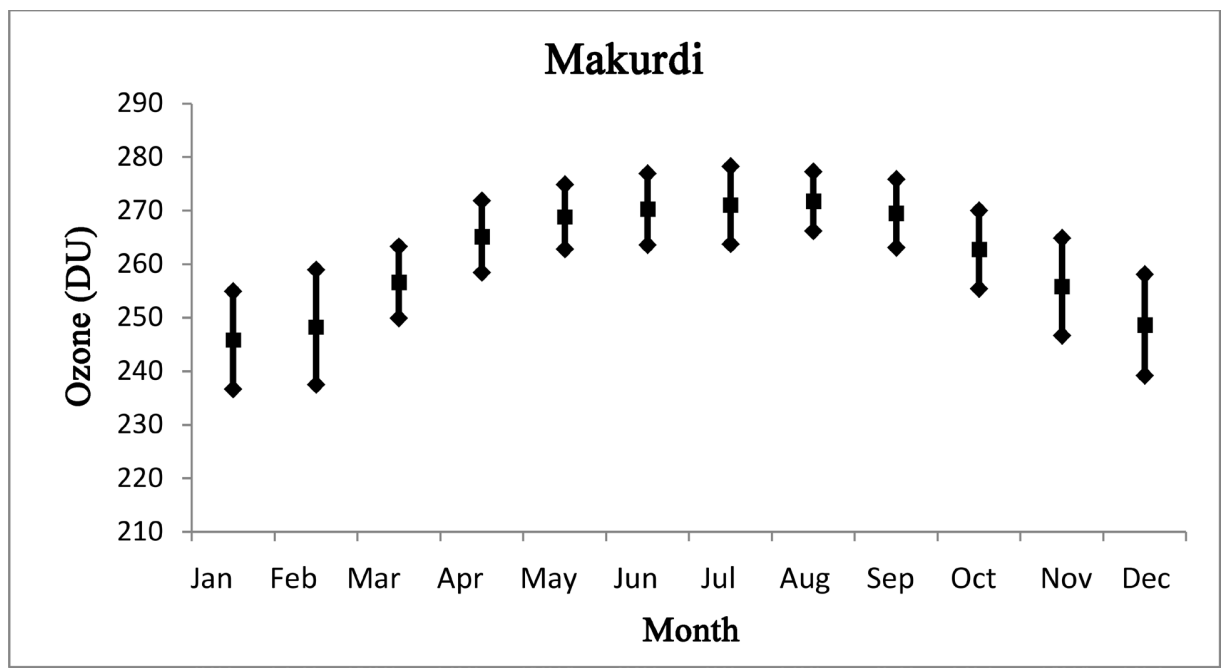

Figure 7. Monthly variation of ozone concentrations in Makurdi (1998-2012). 
and pushed pole-ward and downward. It has been shown that the atmospheric dynamics are the major factor in the variation of ozone concentration over the tropics [7] [8] [10] [14]. Conversely, Calabar and Port Harcourt show high degree of variance in all the months while Kano and Maiduguri indicate low degree of variance. The average monthly maximum ozone concentration was observed in Kano and Maiduguri stations as shown in Table 1. This could be as a result of the proximity of the stations to the equator that is, latitudinal factor. The farther away a station is located from the equator, the more the ozone concentration, due to reduction in energy from atmospheric heat engine to lift off $\mathrm{O}_{3}$. The intensity of solar radiation on a region affects the concentration of ozone. The convective activities strengthen some atmospheric phenomena such as extra-tropical suction pump action that lifts ozone from tropics to extra-tropics [8].

On the other hand, the minimum ozone concentration values mostly occurred in Calabar and Port Harcourt stations. These stations loose more of their ozone rich air to the extra-tropical region as a result of the increase in the energy that lifts enough ozone from the tropics to extratropical region. Again, the observed

Table 1. Analysis of maximum and minimum ozone variations in different stations under study from 1998 to 2012.

\begin{tabular}{|c|c|c|c|c|c|c|}
\hline Year & Mean (DU) & Max. ozone in DU (stations) & $\begin{array}{c}\text { Month } \\
\text { (maximum) }\end{array}$ & Min. ozone in DU (stations) & $\begin{array}{c}\text { Month } \\
\text { (minimum) }\end{array}$ & $\%$ variability \\
\hline 1998 & 258.925 & 276.7 (Kano \& Maiduguri) & August & 235.6 (Calabar \& PH) & January & 14.85 \\
\hline 1999 & 265.877 & 279.2 (Kano) & June & 242.8 (Kano) & January & 13.04 \\
\hline 2000 & 263.813 & 281.9 (Maiduguri) & May & 242.7 (Calabar \& PH) & December & 13.91 \\
\hline 2001 & 263.079 & 281.9 (Kano) & May & 243.1 (Calabar \& PH) & January & 13.74 \\
\hline 2002 & 262.462 & 276.8 (Kano) & June & 243.2 (Kano) & January & 12.14 \\
\hline 2003 & 260.079 & 280.4 (Kano) & May/June & 243.0 (PH \& Calabar) & January & 13.34 \\
\hline 2004 & 263.476 & 281.1 (Kano) & June & 238.9 (Kano \& Maiduguri) & January & 15.01 \\
\hline 2005 & 257.836 & 274.3 (Kano) & May & 240 (Kano) & December & 12.50 \\
\hline 2006 & 262.469 & 280.5 (Kano) & July & 238.3 (Kano \& Maiduguri) & January & 15.05 \\
\hline 2007 & 257.954 & 275.0 (Kano) & May & 241.3 (Calabar) & January & 12.26 \\
\hline 2008 & 263.881 & 278.8 (Kano \& Maiduguri) & July & 238.3 (Maiduguri) & January & 14.53 \\
\hline 2009 & 259.668 & 276.2 (Kano) & May & 237 (Calabar \& PH) & December & 14.19 \\
\hline 2010 & 260.419 & 274.7 (Kano) & July & 237 (Calabar \& PH) & January & 13.72 \\
\hline 2011 & 262.249 & 275.1 (Kano) & May & $248.3(\mathrm{PH})$ & December & 9.74 \\
\hline 2012 & 260.804 & 283.8 (Kano) & May & 238.5 (Kano \& Maiduguri) & December & 15.96 \\
\hline
\end{tabular}

NB: PH signifies Port Harcourt; Mean = annual mean of ozone concentration; Maximum ozone = maximum ozone value; Month maximum $=$ month of maximum ozone concentration; Minimum ozone $=$ minimum value; Month minimum $=$ month of minimum ozone concentration; Variability $(\%)=\left[\frac{\text { Range }}{\text { maximum }} \times 100\right]$; Average variability $(\%)=13.612$. 
phenomenon could be through transportation of ozone content through the influence of Brewer-Dobson circulation or it could also be attributed to the fact that during wet season, there is the mechanism of low pressure and lower tropopause height phenomenon, therefore, total ozone enhancement. This is as suggested by [15] [16] [17] [18] [19] that a shift in the ozone profile becomes largest near the tropopause and shows a negligible value closer to the lowermost stratosphere. Hence, according to [6], ozone is a tracer agent to synoptic scale dynamic processes observed in this region (upper troposphere and lowermost stratosphere). Interestingly, Port Harcourt and Calabar experience longer wet season and are under the rainforest and mangrove climatic zones and are also located at the coastal region. This implies that, stations with high ozone concentration coincided with the stations with low ozone variability while stations with low concentration ozone coincided with the stations with high ozone variability.

Using spearman correlation analysis equation (3c), it was inferred from Table 2 that enhanced ozone concentration caused reduction in the observed temperature.

This could be possible because, during the wet season when total ozone concentration is enhanced, there is expected increase in cloud cover which invariably minimizes the solar radiation and hence, reduction in temperature. Stations, such as Ilorin, Calabar, Makurdi, Lagos and Port Harcourt had a strong negative correlation between ozone concentration and temperature at 0.05 significant level. The result also revealed that the dry season in Nigeria is characterized by high surface temperature when total $\mathrm{O}_{3}$ value is at its minimal. Furthermore, temperature showed a weak positive correlation with ozone concentration in Kano and Maiduguri this could be attributed to latitudinal effect and their existing features which qualify the regions to be classified as Sudan Savanna climatic zone. Hence, this phenomenon (increase surface temperature during dry season) could result to high dehydration of water vapour in these stations. It was observed that duration of dry season gets prolonged as one moves farther north that is, Kano and Maiduguri.

It is inferred from Figures 8-11 that descriptively, both $\mathrm{O}_{3}$ and the amount of

Table 2. Correlation coefficient (r) between ozone and climatic parameter (temperature and rainfall) from 1998 to 2012.

\begin{tabular}{ccc}
\hline Stations & Temperature $\left({ }^{\circ} \mathrm{C}\right)$ & Rainfall $(\mathrm{mm})$ \\
\hline Calabar & -08392 & 0.9510 \\
Lagos & -08881 & 0.7692 \\
Makurdi & -0.7832 & 0.9580 \\
Port Harcourt & -0.8531 & 0.9301 \\
Ilorin & -0.7900 & 0.8951 \\
Kano & 0.4965 & 0.8685 \\
Maiduguri & 0.3776 & 0.8049 \\
\hline
\end{tabular}




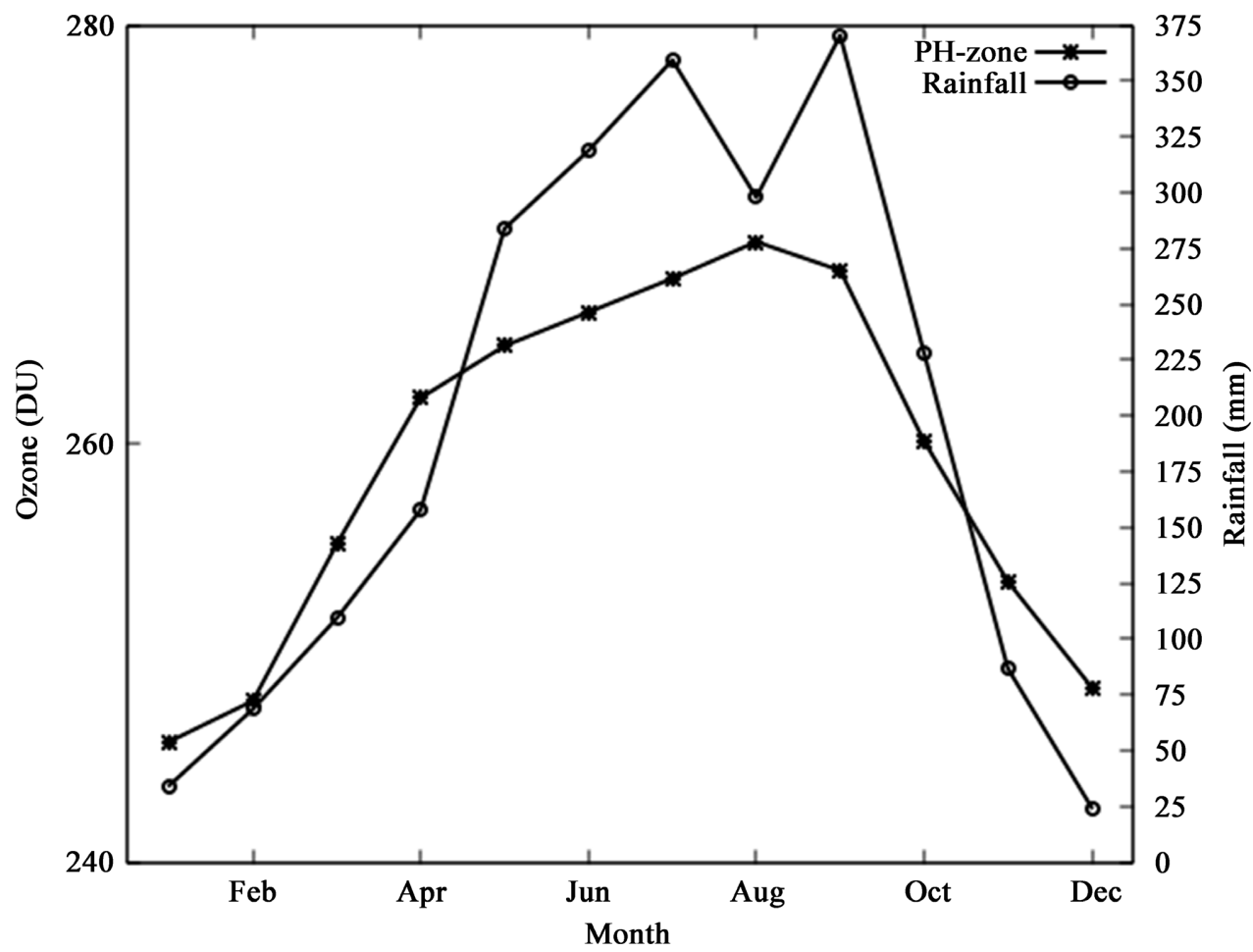

Figure 8. Relationship between ozone concentration and rainfall pattern in Port Harcourt (1998-2012).

rainfall enhanced during wet season observed in Nigeria that is from Aprilthrough September throughout the period of study. In the Southern stations as observed from Figures 8-10, the $\mathrm{O}_{3}$ concentration averagely peaked before or after August break (a temporary dry season period during wet season).

These stations experienced longer rainfall and shorter dry season with less ozone concentration compare to Northern stations (Figure 11) that had longer dry season and shorter rainfall duration with more of $\mathrm{O}_{3}$ content which peaked about the onset of rainfall season April. This could be attributed to latitudinal effect and they are in the coastal region with more vegetation as well. August break observed in these Southern stations is shorter in duration. Southern stations also experience rainfall earlier (around late February to early March) and the season can extend up to late October to early November before it comes to an end.

The overall patterns of monthly variation of rainfall with ozone showed a strong positive correlation with correlation coefficient $(r)$ of $0.95,0.77,0.96$, 0.93, 0.90, 0.87 and 0.81 for Calabar, Lagos, Makurdi, Port Harcourt, Ilorin, Kano and Maiduguri respectively. The observed high concentration of ozone in rainy season can be attributed to reduction in strength of atmospheric dynamic that is responsible for the transportation of ozone rich air from tropical stratosphere into high and mid latitudinal region. In other words, some particulate matters such as aerosols and gases are prone to destruction of ozone. Some of the matters are soluble in water thereby being washed off by rain during wet 
season leading to maximum ozone concentration during rainy season as observed in the study. Again, the result of maximum ozone concentration could also be attributed to the fact that during wet season, there is the mechanism of low pressure and lower tropopause height phenomenon, therefore, total ozone enhancement.
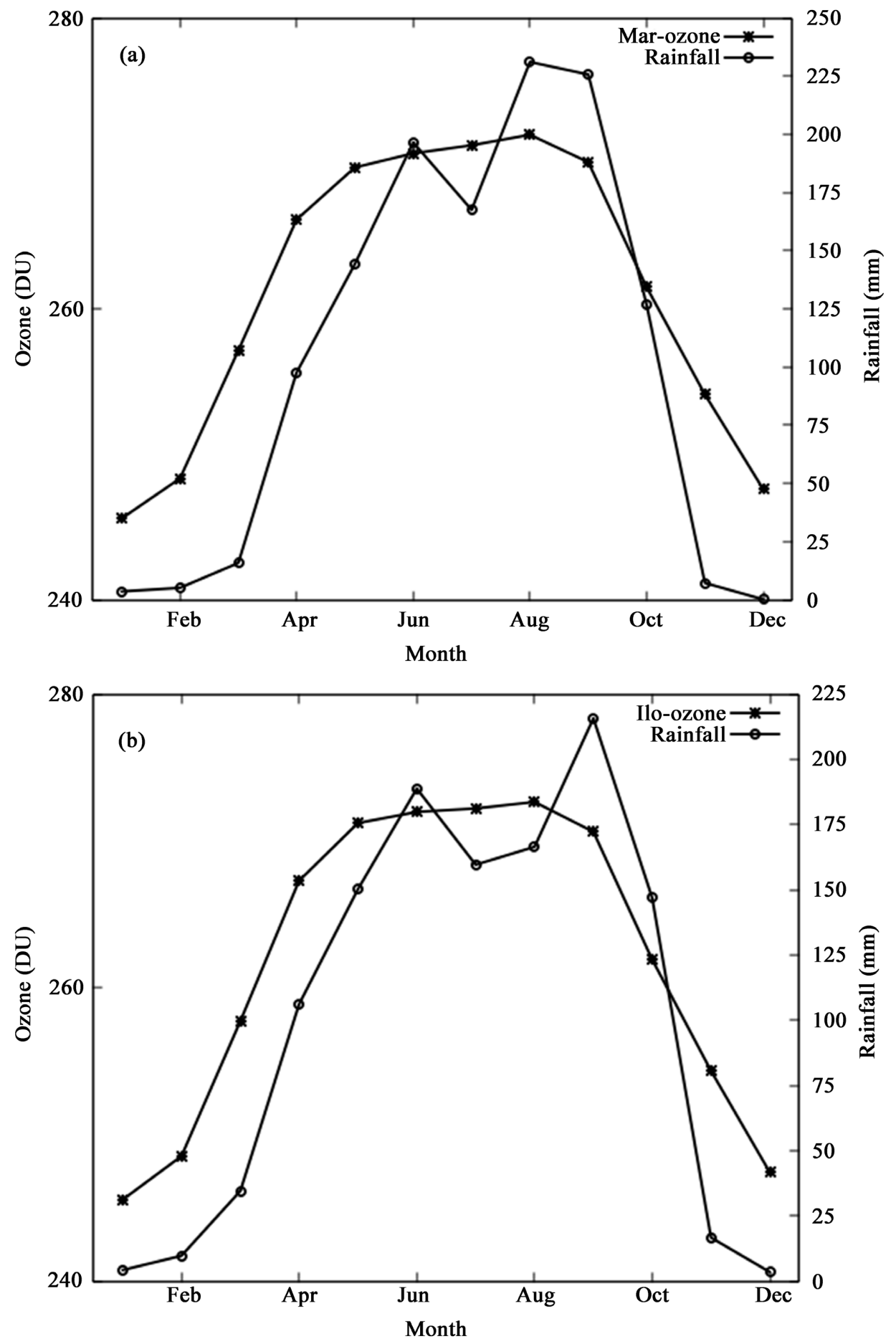

Figure 9. Relationship between ozone concentration and rainfall pattern in (a) Makurdi, (b) Ilorin (1998-2012). 

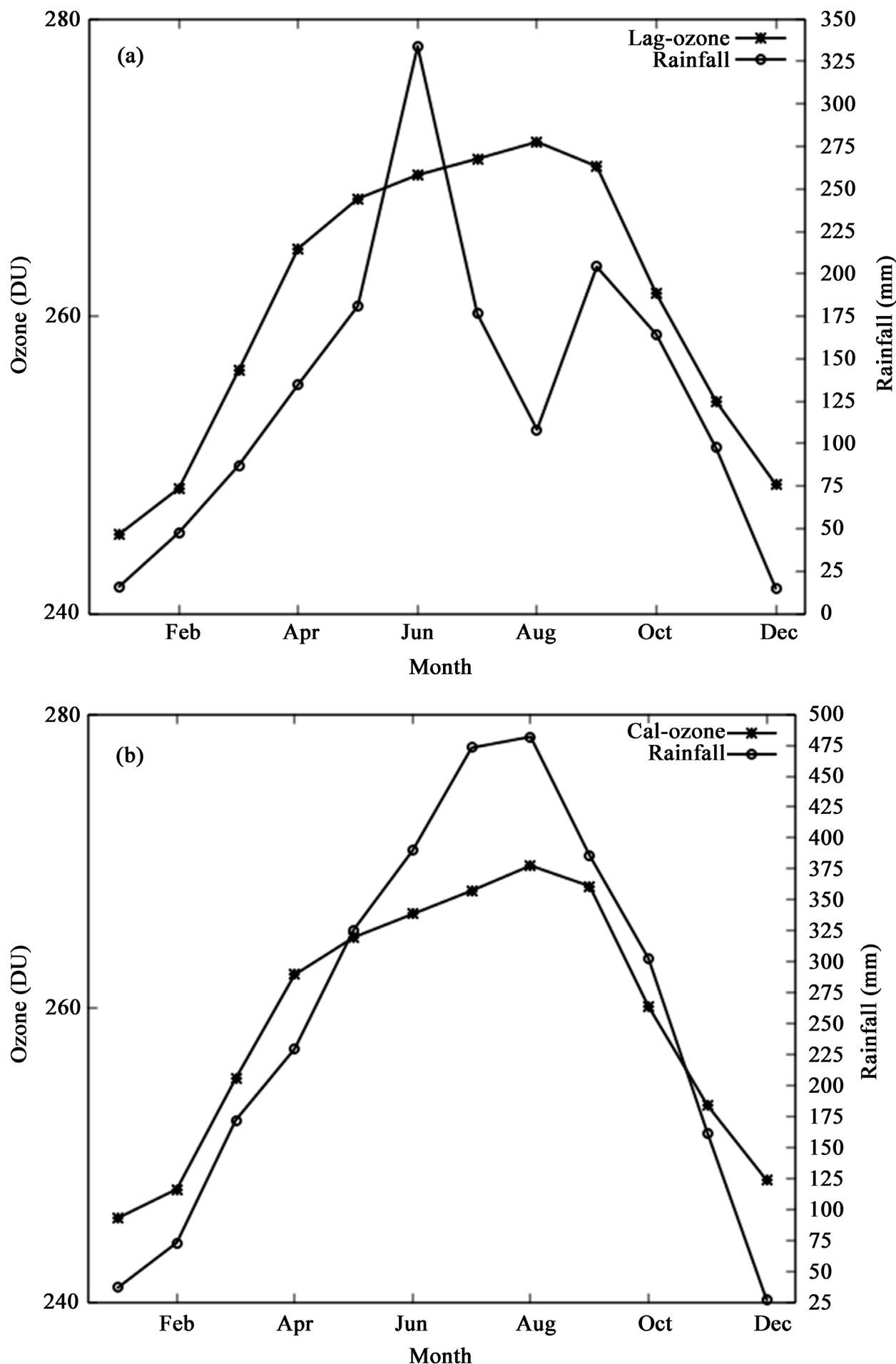

Figure 10. Relationship between ozone concentration and rainfall pattern in (a) Lagos, (b) Calabar (1998-2012).

Interestingly, it is equally observed from Figures $12-17$ that ozone variation is inversely related to temperature throughout the period of study. This inference suggests that when there is less $\mathrm{O}_{3}$ concentration, sun rays penetrate more and thereby enhance the temperature and vice versa. The stations in the Northern 
part of the country experienced higher temperature than the Southern stations. However, Figure 12, Figure 14 and Figure 16 have a missing data point in $\mathrm{Au}-$ gust in which the amount of temperature (presumably) is zero.
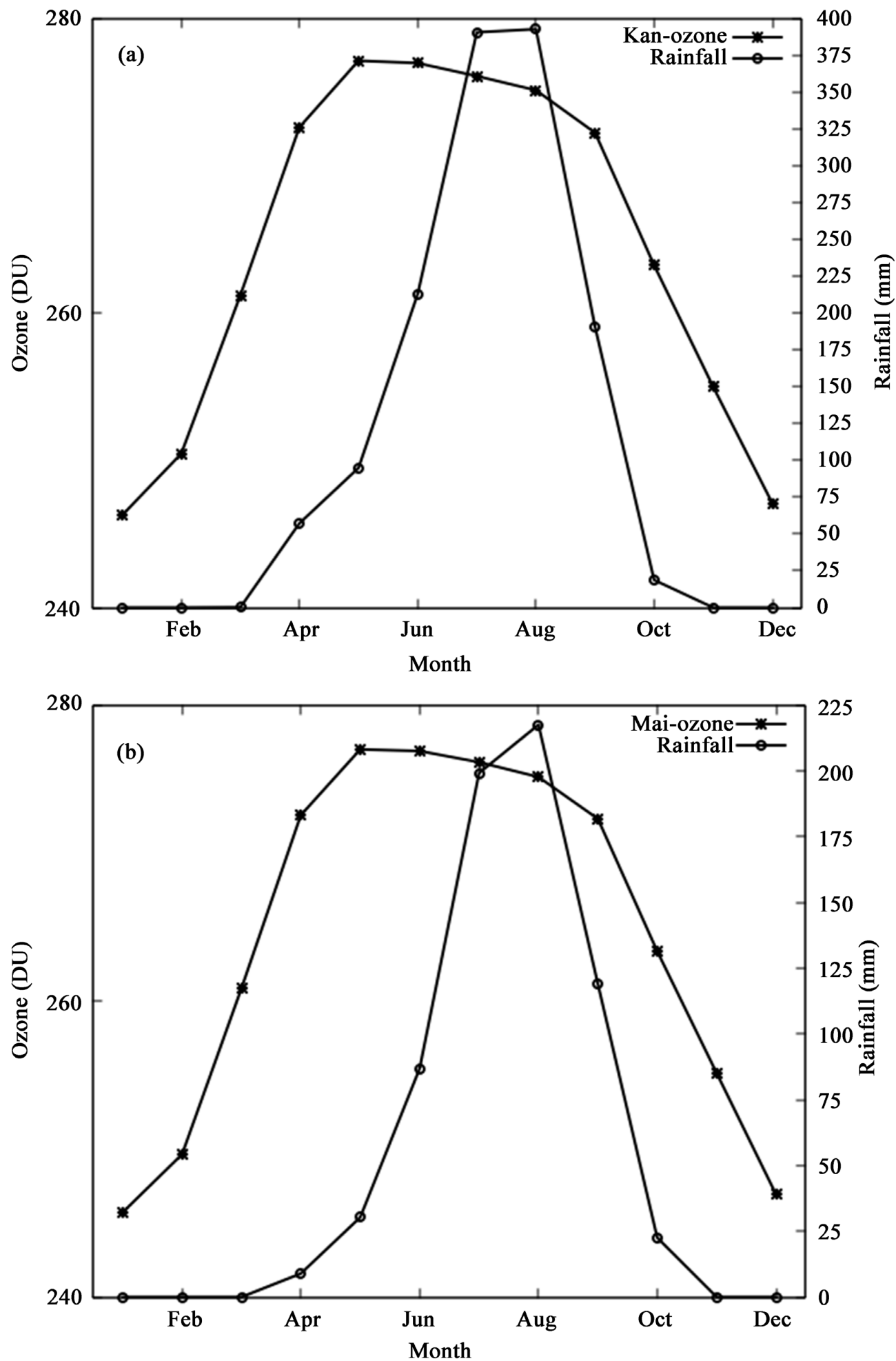

Figure 11. Relationship between ozone concentration and rainfall pattern in (a) Kano, (b) Maiduguri (1998-2012). 


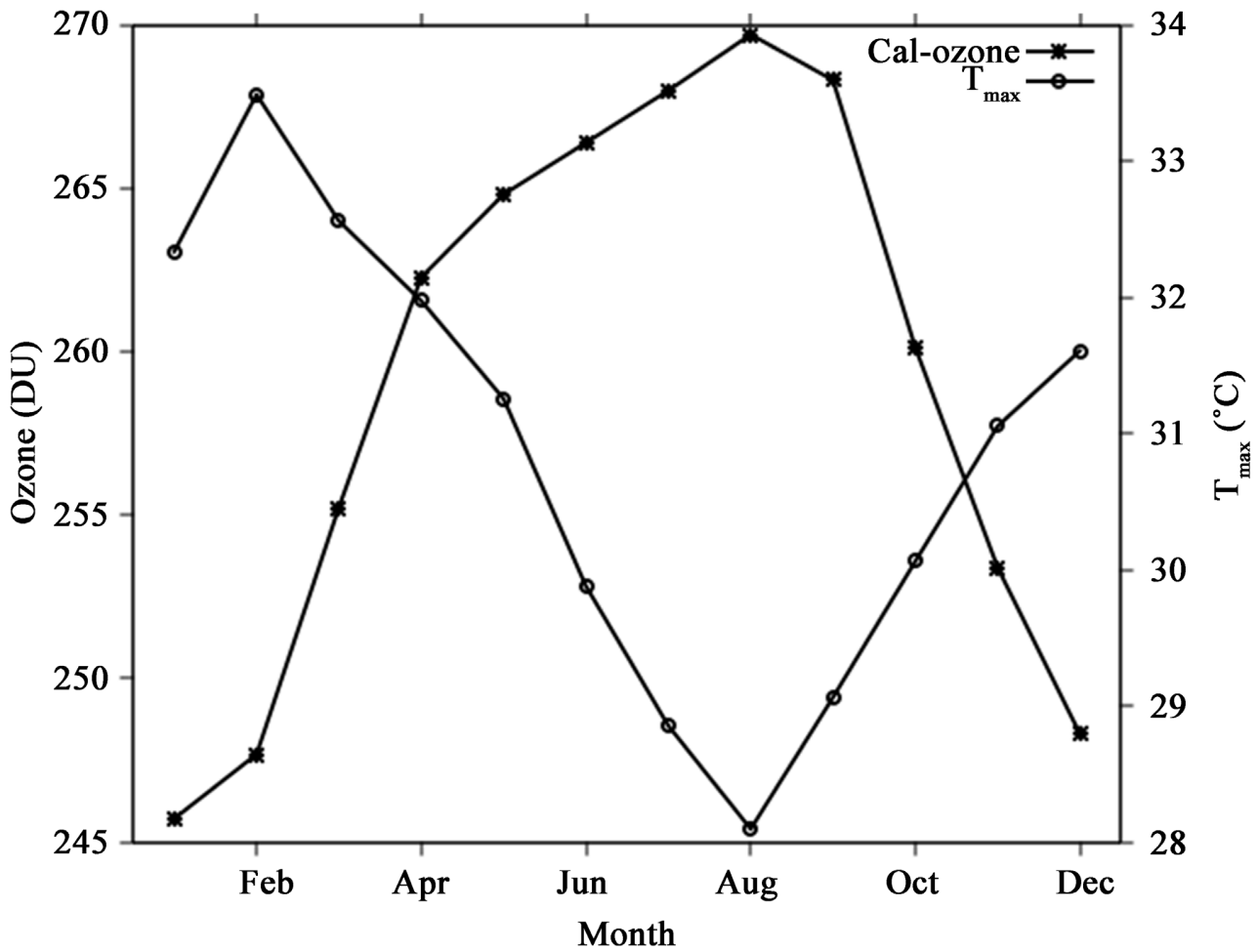

Figure 12. Relationship between total ozone and temperature for Calabar from 1998-2012.

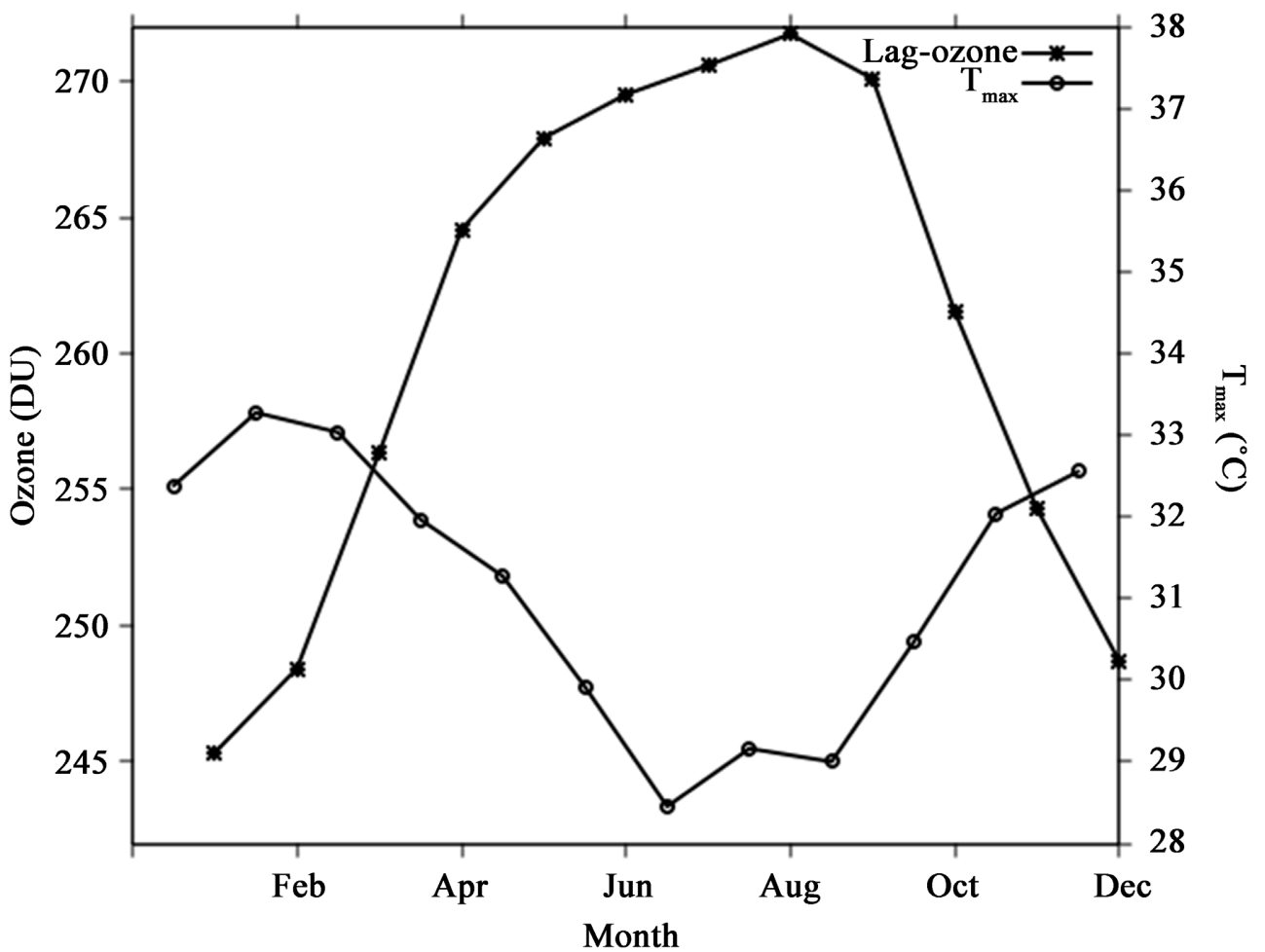

Figure 13. Relationship between total ozone and temperature for Lagos from 1998-2012. 


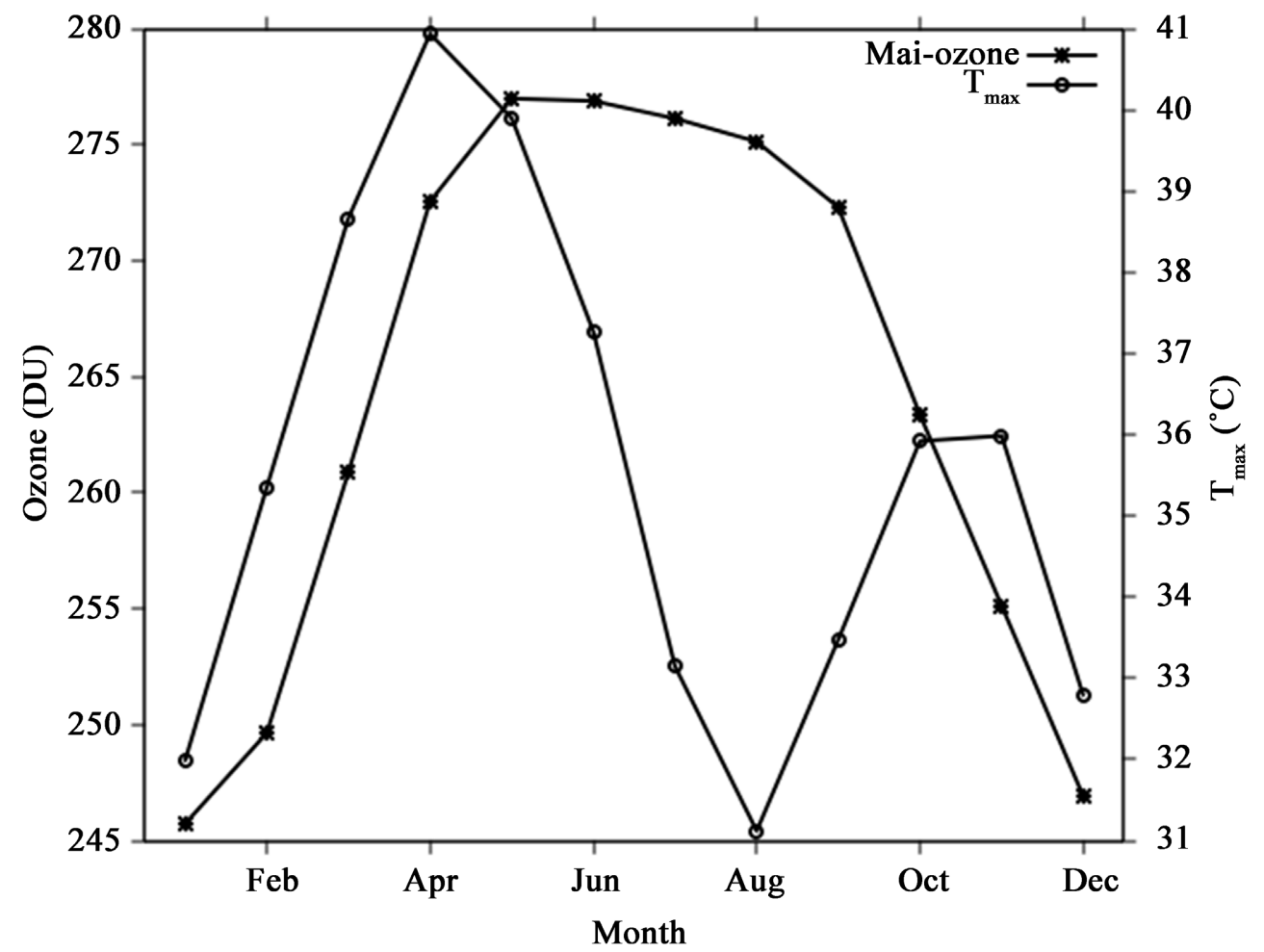

Figure 14. Relationship between total ozone and temperature for Maiduguri from 1998-2012.

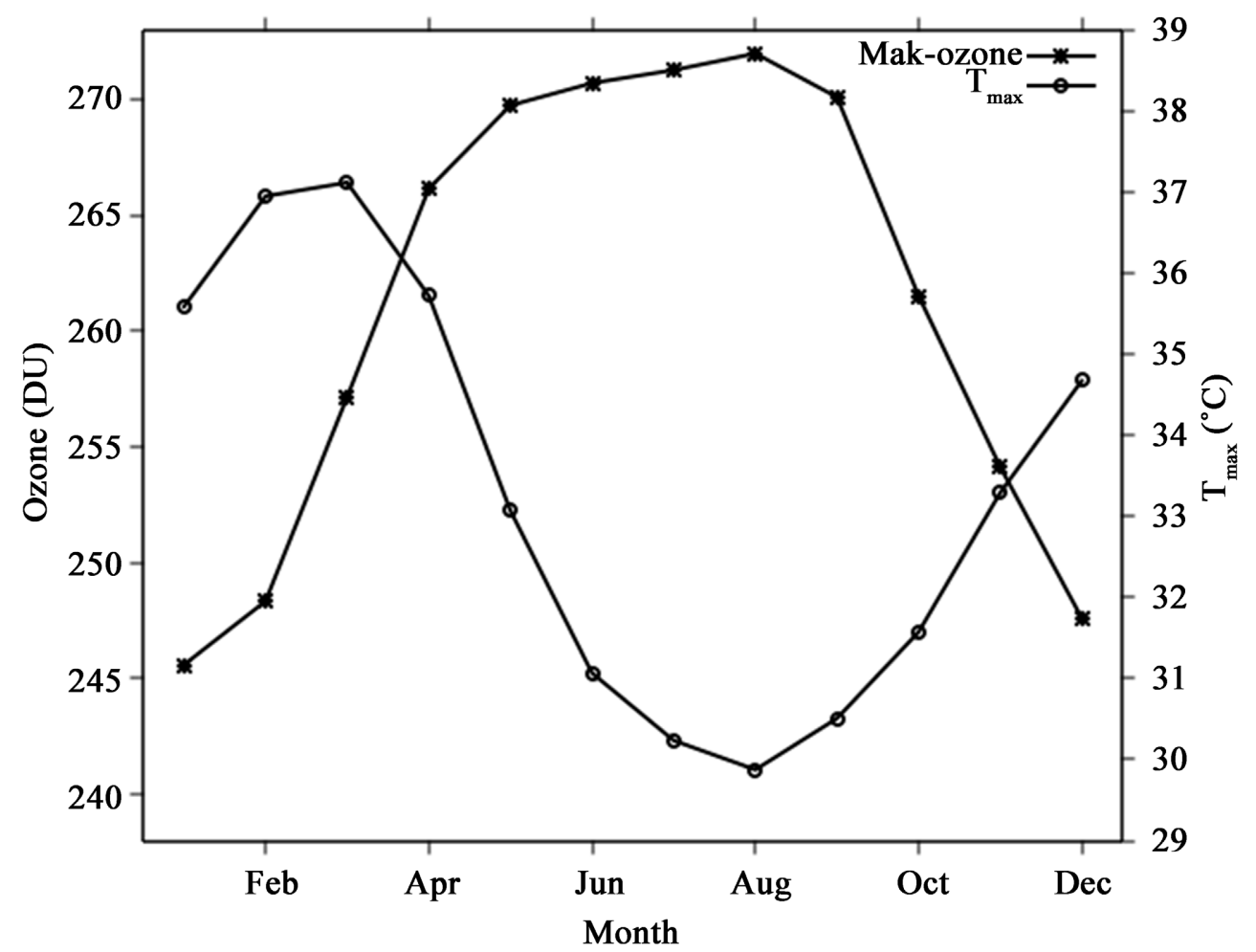

Figure 15. Relationship between total ozone and temperature for Makurdi from 1998-2012. 


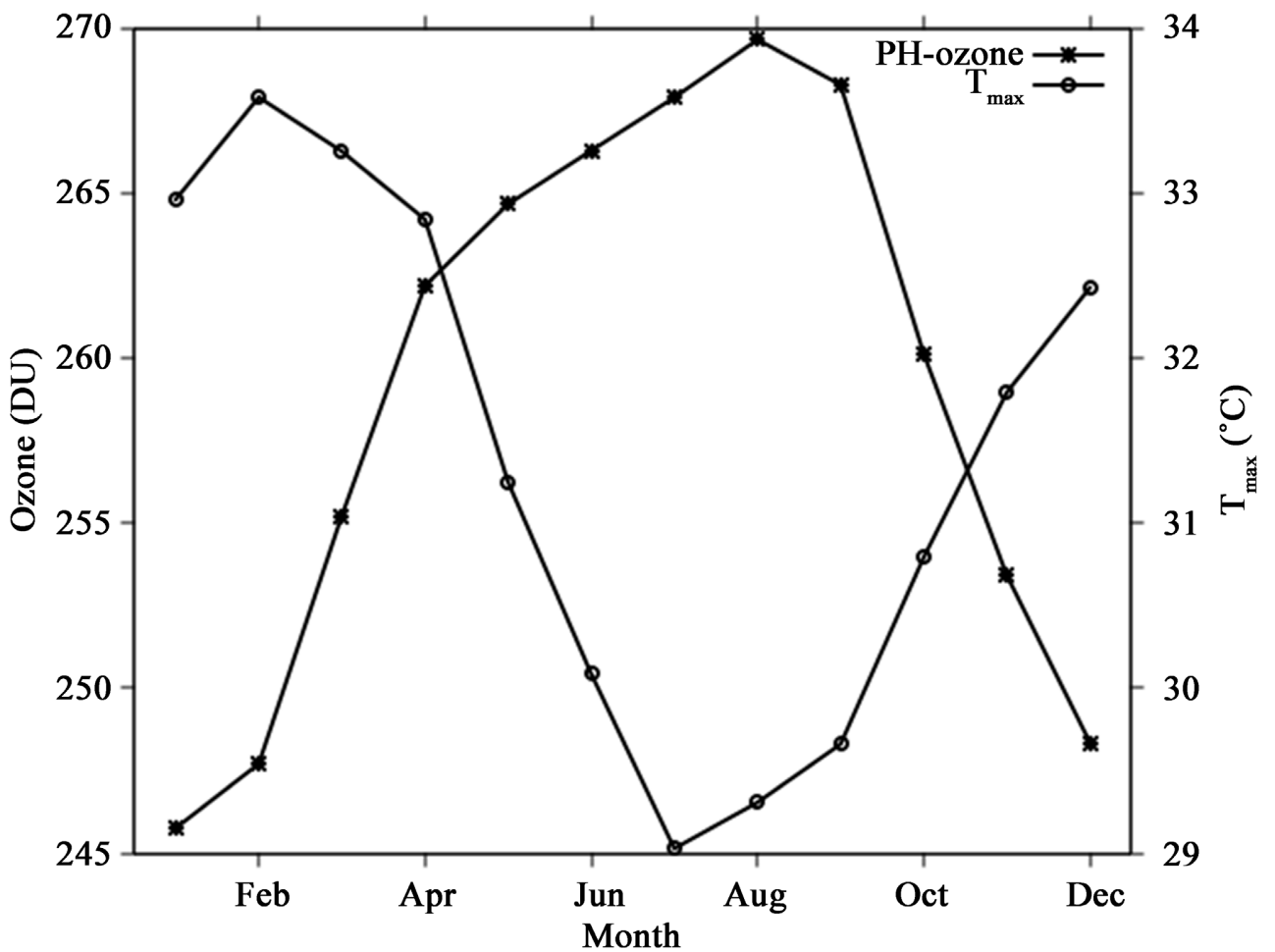

Figure 16. Relationship between total ozone and temperature for Port Harcourt from 1998-2012.

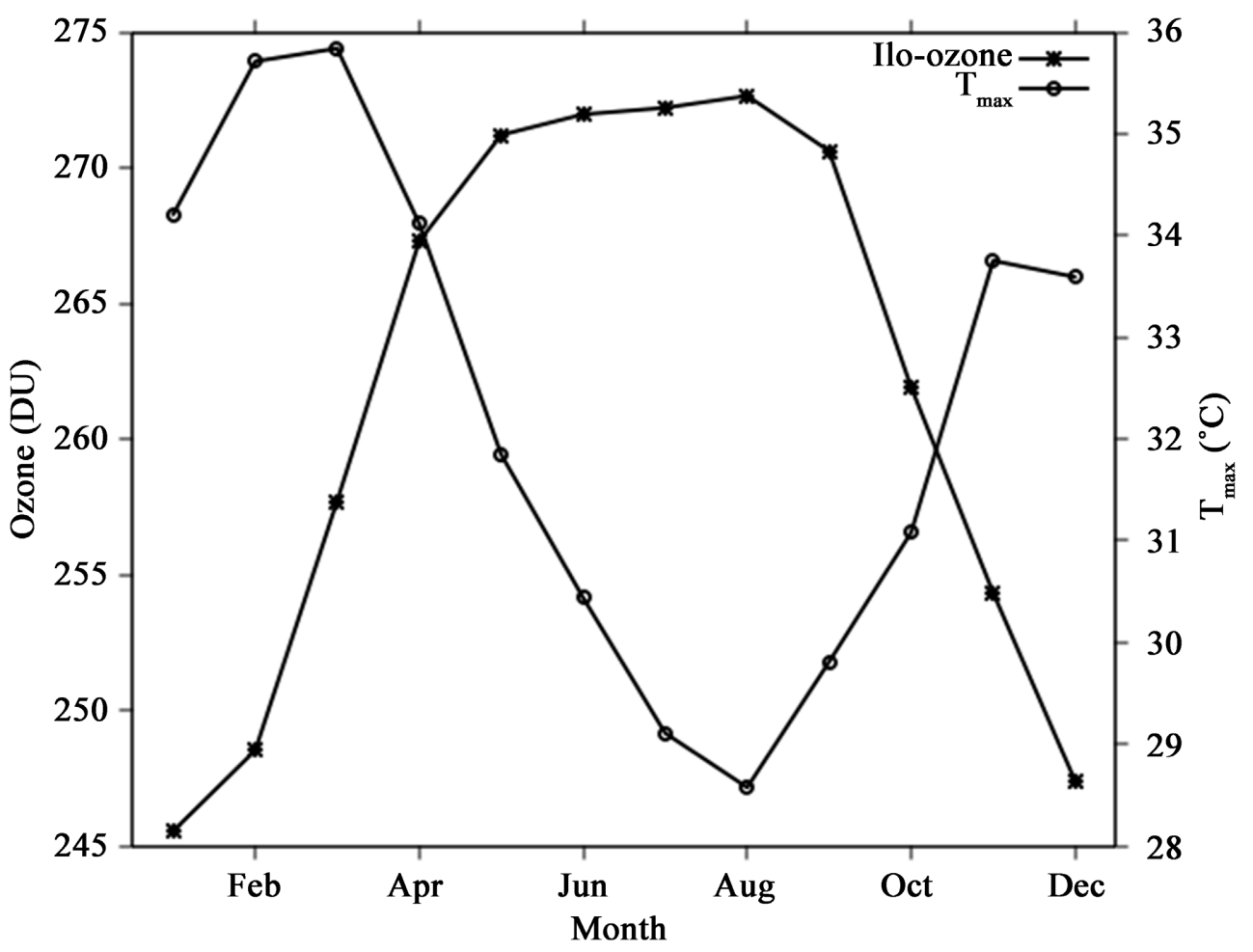

Figure 17. Relationship between total ozone and temperature for Ilorin from 1998-2012. 


\section{Conclusions}

From the study of investigating the contributions of total ozone variation on rainfall and temperature during the two seasons obtained in Nigeria (dry and wet seasons), we make the following deductions:

1) It is ascertained that ozone concentration shows strong seasonality. This implies that ozone concentration is low in dry season and high in rainy season.

2) It was equally ascertained from our study that ozone concentration has high variability in dry season and low variability in rainy season. The observed trend of ozone variability in all the stations shows that the ozone variation in Nigeria could be caused by natural occurrences such as wind, low pressure and lower tropopause height phenomenon, climatic features and latitudinal effects.

3) Consequently, it is inferred from this study that the Southern part of the country noted lower ozone concentration than the Northern parts, which experience prolonged wet season and shorter dry season duration.

4) It was also noted that ozone concentration was positively correlated with rainfall and negatively correlated with temperature. Though not considered in this study, enhanced ozone could indirectly cause an increase in rainfall amount by (presumably) contributing to cloud cover enhancement in wet season and vice versa during dry season. Hence, if adequately monitored, ozone variation could be a predicting tool to meteorological parameters such as temperature and rainfall in Nigeria.

\section{Acknowledgments}

The authors are thankful to Goddard Institute for Space Study, USA, the owner of the satellite Earth Probe Total Ozone Mass Spectroscopy (EPTOMS) and the World Ozone and Ultraviolet Radiation Data Centre. We are equally grateful to Nigerian Meteorological Agency (NIMET) Lagos for the provision of temperature and rainfall data.

\section{Conflicts of Interest}

The authors declare no conflicts of interest regarding the publication of this paper.

\section{References}

[1] Longstreth, J., Grujl, F.R., Kripke, M.L., Abseck, S., Arnold, F., Slaper, H.L., Velders, G., Takizawa, Y. and Van der Leun, J.C. (1998) Environmental Effects of Ozone Depletion 1998 Assessment. United Nations Environmental Program (UNEP), 1998 Assessment.

[2] Nandita, D. and Iyer, K. (2005) Study of Variations in Columnar Ozone Concentration at Rajkot. The Journal of Indian Geophysical Union, 9, 189-196.

[3] Boynard, A., Clerbaux, C., Coheur, P., Hurtmans, S., Turquety, S., George, M., Hadji-Lazaro, J., Keim, C. and Meyer-Arnek, J. (2009) Measurements of Total and Tropospheric Ozone form IASI: Comparison with Correlative Satellite, Ground-Based and Ozonesonde Observations. Atmospheric Chemistry and Physics, 9, 6271-6271. 
https://doi.org/10.5194/acp-9-6255-2009

[4] Hader, D.P., Helbling, E.W., Williamson, C.E. and Worrest, R.C. (2010) Effects of UV Radiation on Aquatic Ecosystem and Interaction with Climate Change. United Nations Environment Program (UNEP), 2010 Assessment.

[5] Sivasakthivel, T. and Siva Kumar Reddy, K.K. (2011) Ozone Layer Depletion and Its Effects: A Review. International Journal of Environmental Science and Development, 2, 30-37. https://doi.org/10.7763/IJESD.2011.V2.93

[6] Holton, J.R., Haynes, P.H., McIntyre, M.E., Douglass, A.R., Rood, R.B. and Pfister, L. (1995) Stratosphere-Troposphere Exchange. Reviews of Geophysics, 33, 403-439. https://doi.org/10.1029/95RG02097

[7] Isikwue, B.C. and Okeke, F.N. (2009) Effects of Some Atmospheric Parameters on the Dynamics of Lower Stratospheric Ozone in the Low Latitude. The Pacific Journal of Science and Technology, 10, 686-692.

[8] Okoro, E. and Okeke, F.N. (2017) Effects of Zonal Wind on Stratospheric Ozone Variations over Nigeria. International Journal of Remote Sensing, 38, 1665-1681. https://doi.org/10.1080/01431161.2017.1286053

[9] Pinedo-Vega, J, Molina-Almaraz, M, Ríos-Martínez, C, Mireles-García, F. and Dávila-Rangel, J. (2017) Global and Hemispherical Interannual Variation of Total Column Ozone from TOMS and OMI Data. Atmospheric and Climate Sciences, 7, 247-255. https://doi.org/10.4236/acs.2017.73017

[10] Akinyemi, M.L. (2007) The Influence of Some Atmospheric Phenomena on Total Ozone Concentration over the Tropics. Australian Journal of Basic and Applied Sciences, 1, 497-505.

[11] Akinyemi, M.L. and Uhuegbu C.C. (2009) The Interconnectivity of Weather System and Ozone Concentration Over West Africa. Journal of Science and Technology, 29, 52-59. https://doi.org/10.4314/just.v29i3.50055

[12] Isikwue, B.C. and Okeke, F.N. (2012) Influence of AAM-LOD on the Lower Stratospheric Ozone Transport over Lagos-Nigeria. Turkish Journal of Physics, 38, 299-307.

[13] Ejimofor, C.S., Okoro, E.C. and Sivla, W.T. (2020) Effects of Elevated Humidity on Stratospheric Ozone Content in the Tropics. International Journal of Physical Sciences, 15, 182-193. http://www.academicjournals.org/IJPS

[14] Obiekezie, T.N. (2008) Sunshine Activities and Total Column Ozone Variation in Lagos, Nigeria. Moldavian Journal of the Physical Sciences, 8, 169-172.

[15] Steinbrecht, W., Claude, H., Kohler, U. and Hoinka, K.P. (1998) Correlations between Tropopause Height and Total Ozone: Implications for Long-Term Changes. Journal of Geophysical Research: Atmospheres, 103, 19183-19192. https://doi.org/10.1029/98JD01929

[16] Chandra, S., Ziemke, J.R. and Martin, R.V. (2003) Tropospheric Ozone at Tropical and Middle Latitudes Derived from TOMS/MLS Residual: Comparison with a Global Model. Journal of Geophysical Research: Atmospheres, 108, Article No. 4291. https://doi.org/10.1029/2002JD002912

[17] Varotsos, C. (2004) Atmospheric Pollution and Remote Sensing: An Implication for the Southern Hemisphere Ozone Hole Split in 2002, and the Northern Mid-Latitude Ozone Trend. Advances in Space Research, 33, 249-253. https://doi.org/10.1016/S0273-1177(03)00473-3

[18] Pan, L.L., Paulik, L.C., Honomichl, S.B., Munchak, L.A., Bian, J., Selkirk, H.B. and Vomel, H. (2014) Identification of the Tropical Tropopause Transition Layer Using the Ozone-Water Vapor Relationship. Journal of Geophysical Research: Atmos- 
pheres, 119, 3586-3599. https://doi.org/10.1002/2013JD020558

[19] Okoro, E.C., Yan, Y.H., Bisoi, S.K. and Zhang, Y. (2021) Response and Periodic Variation of Total Atmospheric Ozone to Solar Activity over Mountain Waliguan. Advances in Space Research, 68, 2257-2271.

https://doi.org/10.1016/j.asr.2021.06.021 